\title{
Beberapa Faktor yang Mempengaruhi CSR Disclosure Pada Sektor Pertambangan yang Terdaftar di BEI Periode 2015-2018
}

\author{
${ }^{1}$ Ferent Vanessa, ${ }^{2}$ Carmel Meiden \\ ${ }^{1,2}$ Akuntansi, Institut Bisnis dan Informatika Kwik Kian Gie
}

\author{
Alamat Surat \\ Email: ferent.vanessa121266@gmail.com
}

\author{
Article History: \\ Diajukan: 18 Juni 2020; Direvisi: 27 Oktober 2020; Accepted: 28 Oktober 2020
}

\begin{abstract}
ABSTRAK
Tanggung jawab sosial perusahaan merupakan bentuk kewajiban yang mendorong perusahaan untuk melakukan pengungkapan terkait pelaksanaannya sebagai bentuk transparansi perusahaan terhadap masyarakat dan lingkungan. Penelitian ini bertujuan untuk mengetahui beberapa faktor yang dapat mempengaruhi pengungkapan tersebut. Objek penelitian ini adalah perusahaan sektor pertambangan yang terdaftar di Bursa Efek Indonesia periode 2015-2018. Pengambilan sampel dilakukan dengan menggunakan teknik non probability sampling metode purposive judgement yang menghasilkan 12 perusahaan sampel dengan 48 data amatan. Metode analisis yang digunakan adalah analisis statistik deskriptif, uji kesamaan koefisien, uji asumsi klasik, dan analisis regresi linear berganda yang diolah dengan program SPSS 25 . Hasil penelitian ini menunjukkan bahwa komisaris independen dan komite audit berpengaruh secara positif dan signifikan terhadap pengungkapan tanggung jawab sosial perusahaan, sementara profitabilitas, leverage, dan kepemilikan manajerial tidak berpengaruh signifikan.
\end{abstract}

Kata kunci: Pengungkapan tanggung jawab sosial perusahaan; profitabilitas; leverage, kepemilikan manajerial; komisaris independen; komite audit

\begin{tabular}{l} 
ABSTRACT \\
\hline Corporate social responsibility is a form of obligation that encourages companies to make \\
disclosures related to its implementation as a form of corporate transparency towards society and \\
the environment. This study aims to determine several factors that can affect this disclosure. This \\
research's object is mining sector companies listed on the Indonesia Stock Exchange for the period \\
2015-2018. Sampling was done using a non-probability sampling technique purposive judgment \\
method, which resulted in 12 sample companies with 48 observational data. The analytical method \\
used is descriptive statistical analysis, coefficient similarity test, classical assumption test, and \\
multiple linear regression analysis processed with the SPSS 25 program. This study indicates that \\
the independent commissioners and audit committee have a positive and significant effect on \\
corporate social responsibility disclosure. Meanwhile, profitability, leverage, and managerial \\
ownership have no significant effect.
\end{tabular}

Keywords: CSRD; profitability; leverage; managerial ownership; board of independence; audit committee

\section{PENDAHULUAN}

Pada beberapa tahun belakangan ini, isu sosial dan kerusakan lingkungan menjadi dua agenda penting yang perlu diperhatikan oleh masyarakat tanpa terkecuali perusahaan yang telah dipandang oleh banyak orang sebagai bagian dari masyarakat. Perusahaan secara ideal diharapkan dapat 
melakukan berbagai tindakan sosial secara nyata sebagai bentuk kontribusinya dalam pemeliharaan lingkungan sekaligus pelestarian sumber daya alam. Implementasi sebagai wujud kontribusi perusahaan tersebut dikenal dengan istilah Corporate Social Responsibility (CSR) atau dalam bahasa Indonesia disebut dengan tanggung jawab sosial perusahan. Tanggung jawab sosial perusahaan dimaknai sebagai komitmen jangka panjang perusahaan untuk bertindak secara etis dan sesuai dengan hukum yang berlaku guna memberi kontribusi dalam pembangunan ekonomi nasional termasuk peningkatan kualitas hidup dan lingkungan bagi karyawan, kelompok sosial, dan masyarakat secara luas (Rokhlinasari, 2016).

Hakikat penerapan tanggung jawab sosial perusahaan didasari pada konsep Triple Bottom Line (TBL) yang diprakarsai oleh Elkington (1997). Konsep TBL meliputi komponen profit, people, dan planet. Melalui konsep ini diharapkan perusahaan tidak hanya berorientasi terhadap laba (profit), namun juga harus memperhatikan kondisi masyarakat (people) dan lingkungan (planet).

Di Indonesia sendiri pengungkapan tanggung jawab sosial perusahaan diatur dalam UndangUndang No 40 tahun 2007 tentang Perseroan Terbatas. Pasal 74 ayat (1) undang-undang tersebut menyatakan bahwa dalam menjalankan kegiatan usahanya di bidang dan atau berkaitan dengan sumber daya alam, perusahaan wajib melaksanakan tanggung jawab sosial dan lingkungan. Dalam kaitannya dengan pengungkapan informasi, pada Undang-Undang No 32 tahun 2009 pasal 68 dikatakan bahwa setiap orang yang melakukan usaha dan/atau kegiatan berkewajiban: mengungkapkan informasi yang terkait dengan perlindungan dan pengelolaan lingkungan hidup secara benar, akurat, terbuka, dan tepat waktu; menjaga keberlanjutan fungsi lingkungan hidup; dan menaati ketentuan tentang baku mutu lingkungan hidup dan/atau kriteria baku kerusakan lingkungan hidup. Dengan demikian dapat dikatakan bahwa pengungkapan tanggung jawab sosial perusahaan di Indonesia sendiri merupakan suatu hal yang diwajibkan. Namun demikian luas pengungkapan informasinya dapat berbeda antara perusahaan yang satu dengan perusahaan lainnya. Hal tersebut dapat terjadi karena adanya perbedaan kepentingan dan strategi yang dijalankan oleh masing-masing perusahaan.

Pengukuran pengungkapan tanggung jawab sosial perusahaan pada umumnya dapat dilakukan dengan berpedoman pada acuan internasional yang dikenal dengan nama GRI Guidelines, sebagaimana yang dilakukan dalam berbagai penelitian di antaranya: Villiers \& Marques (2016); Krisna \& Suhardianto (2016); Asmeri, Alvionita, \& Gunardi (2017). GRI Guidelines merupakan suatu produk pedoman standar yang dibuat oleh badan internasional bernama Global Reporting Initiatives (GRI) yang berkedudukan di Belanda. Pedoman lain yang juga dapat digunakan terkait pengungkapan tanggung jawab sosial perusahaan adalah ISO 26000 dan PROPER (Program Penilaian Peringkat Kinerja Perusahaan dalam Pengelolaan Lingkungan Hidup). ISO 26000 adalah sebuah standar manajemen mutu internasional atau panduan pelaksanaan tanggung jawab sosial perusahaan sebagai bentuk kontribusi jangka panjang perusahaan dalam pembangunan, sementara PROPER didefinisikan sebagai program evaluasi ketaatan dan kinerja melebihi ketaatan penanggung jawab usaha dan/atau kegiatan di bidang pengendalian pencemaran dan/atau kerusakan lingkungan hidup, serta pengelolaan limbah bahan berbahaya dan beracun.

Isu mengenai pentingnya pelaksanaan tanggung jawab sosial perusahaan pada kenyataannya tidak membuat penerapannya dilakukan dengan baik oleh semua perusahaan. Penelitian Dyduch \& Krasodomska (2017); Habbash (2015); Putri \& Suprasto (2016) mengungkapkan rendahnya praktik pengungkapan tanggung jawab sosial perusahaan pada industri secara umum. Hal ini dibuktikan dengan nilai mean atas pengungkapan tanggung jawab sosial masing-masing penelitian sebesar $11,53 \%$; 24\%; dan 33,12\%. Beberapa kasus yang terjadi di Indonesia juga menunjukkan adanya fenomena faktual yang tidak ideal terkait dengan tanggung jawab sosial perusahaan seperti kasus yang dialami PT Aneka Tambang di tahun 2017 di mana masyarakat mengajukan komplain karena perusahaan dianggap tidak menepati janji untuk mengalirkan dana CSR dan tidak melakukan pemberdayaan masyarakat lokal berupa pelatihan (Merdeka.com, diakses 15 September 2019). Pada tahun 2018 PT Adaro Energy juga mendapat tuntutan dari DPR RI untuk lebih memperhatikan pemulihan lingkungan pasca eksploitasi, penerapan tanggung jawab sosial, dan pembangunan 
Pembangkit Listrik Tenaga Uap (PLTU) (DPR.go.id, diakses 15 September 2019). Selanjutnya di awal tahun 2019 PT Medco E\&P sebagai anak perusahaan PT Medco Energi mengalami aksi protes dari masyarakat akibat munculnya aroma tidak sedap di sekitar pabrik akibat limbah pembakaran gas (Kompas.com, diakses 15 September 2019).

Melihat masih banyaknya kasus pelanggaran tanggung jawab sosial perusahaan, menimbulkan pertanyaan mengenai faktor-faktor apa saja yang dapat mempengaruhinya. Berdasarkan beberapa gap penelitian berikut akan dijabarkan faktor-faktor yang dinilai dapat mempengaruhi pengungkapan tanggung jawab sosial perusahaan yaitu profitabilitas, leverage, kepemilikan manajerial, komisaris independen, komite audit, ukuran perusahaan, likuiditas, dan kepemilikan institusional.

Profitabilitas merupakan rasio yang menunjukkan kemampuan perusahaan dalam memperoleh laba dari kegiatan operasionalnya (Lessambo, 2018: 217). Rifqiyah (2016) menyatakan bahwa perusahaan dengan profitabilitas tinggi akan cenderung mendorong manajemen untuk melakukan tanggung jawab sosialnya secara lebih aktif dan mengungkapkan informasinya secara lebih luas. Penelitian oleh Issa (2017); Wahyuningsih \& Mahdar (2018); menunjukkan bahwa profitabilitas berpengaruh positif terhadap pengungkapan tanggung jawab sosial perusahaan. Sementara Rivandi, Saleh, \& Septiano (2017) memperoleh bukti bahwa profitabilitas berpengaruh secara negatif terhadap pengungkapan tanggung jawab sosial perusahaan. Bertolak belakang dengan beberapa penelitian sebelumnya Wulandari \& Sudana (2018) justru tidak menemukan cukup bukti bahwa profitabilitas berpengaruh signifikan terhadap pengungkapan tanggung jawab sosial perusahaan.

Leverage atau solvabilitas mengukur seberapa besar kemampuan perusahaan untuk melunasi kewajiban jangka panjangnya (Robinson, Henry, Pirie, \& Broihahn, 2015: 313). Menurut Dewinta \& Setiawan (2016) leverage didefinisikan sebagai rasio yang digunakan untuk mengukur besarnya aset perusahaan yang dibiayai oleh utang. Semakin tinggi tingkat leverage perusahaan maka timbul kecenderungan bagi manajemen untuk membatasi biaya yang dikeluarkan perusahaan termasuk biaya untuk pengungkapan tanggung jawab sosial. Penelitian Akanfe, Michael, \& Bose (2017) menunjukkan bahwa leverage berpengaruh secara negatif terhadap pengungkapan tanggung jawab sosial perusahaan dan sebaliknya Putri (2017) dalam penelitiannya memperlihatkan pengaruh positif leverage terhadap pengungkapan tanggung jawab sosial perusahaan. Sedangkan Trinanda, Yahdi, \& Rizal (2018) menemukan bahwa leverage tidak berpengaruh signifikan terhadap pengungkapan tanggung jawab sosial perusahaan.

Sukasih \& Sugiyanto (2017) mendefinisikan kepemilikan manajerial sebagai kepemilikan saham oleh manajemen (direksi, komisaris, dan manajer) yang berperan dalam proses pengambilan keputusan. Kepemilikan manajerial menimbulkan peran ganda bagi manajemen yakni sebagai agen dan pemegang saham, hal tersebut tentu dapat menyelaraskan sudut pandang manajemen dengan pemegang saham sehingga manajemen akan lebih berhati-hati dalam menyediakan informasi mengenai tanggung jawab sosial perusahaan. Wulandari \& Sudana (2018) menemukan pengaruh positif kepemilikan manajerial terhadap pengungkapan tanggung jawab sosial perusahaan. Akan tetapi Ginting (2016) memperlihatkan pengaruh negatif kepemilikan manajerial terhadap pengungkapan tanggung jawab sosial. Berbeda dengan kedua penelitian sebelumnya, Robiah \& Erawati (2017) dalam penelitiannya tidak memperoleh cukup bukti adanya pengaruh kepemilikan manajerial terhadap pengungkapan tanggung jawab sosial perusahaan.

Komisaris independen merupakan bagian dari dewan komisaris, di mana anggotanya tidak berhubungan langsung dengan perusahaan (karyawan perusahaan) dan tidak memiliki hubungan istimewa dengan pemegang saham atau pihak lain dalam perusahaan (Susanto \& Joshua, 2018). Keberadaan komisaris independen dapat meningkatkan pengawasan sehingga manajemen akan cenderung mengungkapkan informasi secara lebih luas khususnya terkait tanggung jawab sosial. Yuliani (2019) menunjukkan bahwa komposisi komisaris independen yang semakin besar akan meningkatkan pengungkapan tanggung jawab sosial. Sementara Bansal, Perez, \& Ariza (2018) menemukan hasil yang berbeda dengan Yuliani yaitu komisaris independen berpengaruh negatif terhadap pengungkapan tanggung jawab sosial perusahaan. Di sisi lain Zhou (2019) tidak menemukan cukup bukti adanya pengaruh komisaris independen terhadap CSRD. 
Komite audit memegang peranan penting dalam tata kelola perusahaan untuk meningkatkan kualitas pelaporan keuangan (Mousa, Desoky, \& Khan, 2018) Keberadaan komite audit sebagai pilar penting tata kelola perusahaan diharapkan mampu meminimalisir kelalaian oleh manajemen, meningkatkan kualitas pengambilan keputusan, mengurangi asimetri informasi, dan meningkatkan kinerja auditor yang pada akhirnya berpengaruh pada pelaporan keuangan perusahaan (Buallay \& AlAjmi, 2019). Peranan tersebut pada akhirnya akan mempengaruhi pengungkapan informasi sebagai bagian dari pelaporan keuangan. Laksmi \& Kamila (2018) menemukan bahwa komite audit berpengaruh positif terhadap pengungkapan tanggung jawab sosial perusahaan, sedangkan Sholihin \& Aulia (2018) tidak memperoleh cukup bukti bahwa komite audit berpengaruh terhadap peningkatan atau menurunkan pengungkapan tanggung jawab sosial.

Ukuran perusahaan merupakan skala yang digunakan untuk menentukan besar kecilnya suatu perusahaan (Wiyuda \& Pramono, 2017). Perusahaan besar akan cenderung mendapatkan perhatian lebih dari masyarakat sehingga manajemen akan cenderung mengungkapkan informasi terkait tanggung jawab sosialnya secara lebih luas guna memperoleh kepercayaan dari masyarakat dan investor. Semakin luasnya pengungkapan tanggung jawab sosial ketika ukuran perusahaan semakin besar ditemukan dalam hasil penelitian Julianto \& Sjarief (2016). Namun dalam penelitian Simamora, Nasir, \& Safitri (2017) ditemukan bahwa ukuran perusahaan tidak berpengaruh signifikan terhadap pengungkapan tanggung jawab sosial perusahaan.

Kemampuan perusahaan dalam melunasi kewajiban jangka pendeknya atau sering disebut dengan likuiditas (Purwanti \& Kalbuana, 2016). Tingkat likuiditas yang tinggi mengindikasikan baiknya kinerja keuangan perusahaan, hal ini menyebabkan perusahaan akan mengungkapkan tanggung jawab sosialnya secara lebih luas guna meningkatkan kredibilitasnya. Bukti pengaruh likuiditas terhadap pengungkapan tanggung jawab sosial ditemukan dalam penelitian Octaviani \& Yap (2016) yang menunjukkan pengaruh positif, serta penelitian Rokhman (2015) yang menunjukkan pengaruh negatif. Sementara pada penelitian Hasnia \& Rofingatun (2017) menunjukkan bahwa likuiditas tidak berpengaruh signifikan terhadap pengungkapan tanggung jawab sosial perusahaan.

Proporsi saham suatu perusahaan yang dimiliki oleh institusi dalam hal ini blockholders dan perusahaan yang bergerak di bidang investasi dikenal dengan istilah kepemilikan institusional (Nurziah \& Darmawati, 2014). Kepemilikan institusional dianggap berperan penting dalam mengoptimalkan pengawasan terhadap kinerja manajemen. Pengawasan yang meningkatkan akan mengurangi perilaku oportunistik manajemen sehingga informasi akan semakin banyak diungkapkan kepada pihak luar. Edison (2017) menemukan cukup bukti bahwa kepemilikan institusional berpengaruh positif terhadap pengungkapan tanggung jawab sosial perusahaan, sebaliknya Krisna \& Suhardianto (2016) menyatakan bahwa kepemilikan institusional sebagai pihak luar perusahaan tidak memiliki pengaruh signifikan terhadap pengungkapan sosial dan kinerja perusahaan. Berdasarkan latar belakang tersebut, maka penelitian terkait pengungkapan tanggung jawab sosial perusahaan menjadi hal menarik untuk dilakukan. Rumusan masalah yang dibangun dalam penelitian ini adalah Apakah profitabilitas, leverage, kepemilikan manajerial, komisaris independen, dan komite audit berpengaruh terhadap pengungkapan tanggung jawab sosial perusahaan pada sektor pertambangan yang terdaftar di Bursa Efek Indonesia (BEI) periode 2015-2018. Sementara tujuan dari penelitian ini untuk menguji apakah profitabilitas, leverage, kepemilikan manajerial, komisaris independen, dan komite audit berpengaruh terhadap pengungkapan tanggung jawab sosial perusahaan.

\section{METODE}

Penelitian ini menggunakan sektor pertambangan yang terdaftar di Bursa Efek Indonesia periode 2015-2018 sebagai objek penelitian. Sektor pertambangan terdiri dari empat sub sektor yang meliputi sub sektor batubara, minyak dan gas bumi, logam dan mineral lainnya, serta batu-batuan. Teknik pengumpulan data dalam penelitian ini adalah studi dokumentasi pada data sekunder. Pengambilan sampel dilakukan dengan menggunakan non-probability sampling metode purposive sampling yaitu teknik penentuan sampel dengan menggunakan kriteria tertentu. Kriteria pemilihan sampel adalah sebagai berikut: 
1. Perusahaan pada sektor pertambangan yang terdaftar di BEI selama periode 2015-2018.

2. Perusahaan yang mempublikasikan laporan tahunan dan laporan keuangan selama periode 20152018.

3. Perusahaan yang mempublikasikan laporan tahunan, di mana di dalamnya terdapat data dan informasi yang lengkap untuk penelitian.

4. Perusahaan yang tidak melakukan IPO atau relisting selama periode penelitian 2015-2018.

5. Perusahaan yang tidak delisting selama periode 2015-2018.

6. Perusahaan yang mempublikasikan laporan tahunan dan laporan keuangannya dalam mata uang rupiah.

7. Perusahaan yang memiliki ekuitas positif pada periode 2015-2018. Perusahaan dengan ekuitas negatif tidak dimasukkan ke dalam sampel karena dapat menyebabkan bias pada pengukuran leverage (Fajaryani, 2015).

\subsection{Variabel Penelitian Variabel Dependen}

Penelitian ini menetapkan pengungkapan tanggung jawab sosial perusahaan sebagai variabel dependen. Indikator yang digunakan untuk mengukur luas pengungkapan tanggung jawab sosial berpedoman kepada GRI-G4 dengan jumlah 91 item yang meliputi kategori: economic (EC), environment (EN), human rights (HR), labor practices (LA), society (SO), dan product responsibility (PR), hal ini sesuai dengan penelitian yang dilakukan oleh Singgih, Farida, \& Iwanda (2017) yang menggunakan GRI dalam pengukuran CSR. Indeks pengungkapan tanggung jawab sosial perusahaan dirumuskan sebagai berikut:

$$
C S R D=\frac{\text { Jumlah item CSR disclosure yang diungkapkan }}{91 \text { item CSR disclosure menurut GRI }}
$$

Dalam menghitung indeks pengungkapan tanggung jawab sosial perusahaan, sebelumnya perlu dilakukan pemberian skor pada setiap item pengungkapan, di mana skor 1 diberikan apabila item diungkapkan, sedangkan skor 0 diberikan apabila item tidak diungkapkan.

\section{Variabel Independen}

\section{1) Profitabilitas (PROF)}

Profitabilitas merupakan alat ukur kemampuan perusahaan untuk memperoleh laba dalam kaitannya dengan penjualan, total aktiva dan modal (ekuitas) pada periode tertentu (Sari \& Asiah, 2016). Penelitian ini menggunakan indikator ROA sebagai proksi profitabilitas. Dasar penggunaan indikator tersebut mengacu pada Handoyo \& Jakasurya (2017) yang menggunakan ROA untuk mengukur profitabilitas. ROA dapat dirumuskan sebagai berikut:

\section{2) Leverage (LEV)}

$$
R O A=\frac{\text { Net Income }}{\text { Total Assets }}
$$

Leverage merupakan gambaran proporsi total aset perusahaan yang dibiayai oleh utang (Cahyono, Andini, \& Raharjo, 2016). Penelitian menggunakan indikator DER sebagai proksi leverage. Dasar penggunaan indikator tersebut mengacu pada penelitiaan Dewi \& Sedana (2019). DER dapat dirumuskan sebagai berikut:

$$
D E R=\frac{\text { Total utang }(\text { debt })}{\text { Total ekuitas (equity) }}
$$

\section{3) Kepemilikan Manajerial (KM)}

Suastini, Purbawangsa, \& Rahyuda (2016) mendefinisikan kepemilikan manajerial sebagai kepemilikan saham oleh pihak manajemen yang meliputi manajer, direktur, atau komisaris di mana pihak-pihak tersebut terlibat langsung dalam pengambilan keputusan. Penelitian ini menggunakan 
indikator persentase saham yang dimiliki manajemen sebagai kepemilikan manajerial. Dasar penggunaan indikator tersebut mengacu pada penelitian Ariswari \& Damayanthi (2019) yang merumuskan kepemilikan manajerial sebagai berikut:

$$
K M=\frac{\text { Jumlah saham pihak manajerial }}{\text { Total saham beredar }} \times 100 \%
$$

\section{4) Komisaris Independen (KI)}

Menurut Cahyadi, Purwanti, \& Mardiati (2018) komisaris independen adalah anggota dewan komisaris dari luar perusahaan yang tidak memiliki hubungan istimewa dengan manajemen ataupun terlibat aktif dalam operasional perusahaan di mana komisaris independen ditempatkan. Penelitian ini menggunakan indikator proporsi anggota komisaris independen terhadap keseluruhan anggota dewan komisaris dalam mengukur variabel komisaris independen. Dasar penggunaan indikator tersebut mengacu pada penelitian Naseem et al. (2017). Komisaris independen dapat dirumuskan sebagai berikut:

$$
K I=\frac{\text { Jumlah komisaris independen }}{\text { Jumlah dewan komisaris }} \times 100 \%
$$

\section{5) Komite Audit (KA)}

Berdasarkan Peraturan Otoritas Jasa Keuangan No.13/POJK.03/2017 pasal 1 ayat (7) komite audit didefinisikan sebagai komite yang dibentuk dan bertanggung jawab terhadap dewan komisaris dalam membantu pelaksanaan tugas dan fungsi dewan komisaris. Penelitian ini menggunakan indikator jumlah anggota komite audit dalam mengukur variabel komite audit. Dasar penggunaan indikator tersebut mengacu pada penelitian Sumilat \& Destriana (2017) yang merumuskan komite audit sebagai berikut:

$$
K A=\sum \text { Anggota Komite Audit }
$$

\section{HASIL DAN PEMBAHASAN}

\subsection{Statistik Deskriptif}

Menurut Ghozali (2018: 19) statistik deskriptif merupakan teknik analisis yang menggambarkan atau mendeskripsikan data penelitian melalui nilai minimum, maksimum, rata-rata (mean), standar deviasi, sum, range, kurtosis, dan kemencengan distribusi. Teknik analisis deskriptif yang digunakan dalam penelitian ini adalah nilai minimum, maksimum, mean, dan standar deviasi dari masing-masing variabel. Berikut adalah hasil uji statistik deskriptif setiap variabel:

\begin{tabular}{|l|c|c|c|c|c|}
\hline & $\mathrm{N}$ & Min & Max & Mean & Std. Deviation \\
\hline CSRD & 48 & 0,02 & 0,96 & 0,1996 & 0,24637 \\
\hline PROF & 48 & $-0,72$ & 0,21 & $-0,0062$ & 0,14005 \\
\hline LEV & 48 & 0,04 & 2,23 & 0,9978 & 0,46883 \\
\hline KM & 48 & 0,00 & 0,37 & 0,0402 & 0,10194 \\
\hline KI & 48 & 0,25 & 0,75 & 0,4056 & 0,09518 \\
\hline KA & 48 & 2,00 & 5,00 & 3,1250 & 0,67240 \\
\hline SIZE & 48 & 25,57 & 31,14 & 28,3715 & 1,63821 \\
\hline
\end{tabular}


Berdasarkan hasil uji statistik deskriptif pada tabel di atas diperoleh nilai rata-rata (mean) pengungkapan tanggung jawab sosial sebesar 0,1996 dan standar deviasi sebesar 0,24637; dengan nilai minimum 0,02 yang diperoleh PT Perdana Karya Perkasa Tbk (PKPK) pada tahun 2015 dan 2018; serta nilai maksimum 0,96 yang diperoleh PT Bukit Asam Tbk (PTBA) pada tahun 2015. Variabel profitabilitas yang diukur dengan proksi ROA memperoleh nilai rata-rata $-0,0062$ dan standar deviasi 0,14005; dengan nilai minimum -0,72 yang diperoleh PT Mitra Investindo Tbk (MITI) pada tahun 2015; serta nilai maksimum 0,21 yang diperoleh PT Bukit Asam Tbk (PTBA) pada tahun 2018. Variabel leverage yang diukur dengan proksi DER memperoleh nilai rata-rata 0,9978 dan standar deviasi 0,46883; dengan nilai minimum 0,04 yang diperoleh PT Central Omega Resources Tbk (DKFT) pada tahun 2015; serta nilai maksimum 2,23 yang diperoleh PT Radiant Utama Interinsco Tbk (RUIS) pada tahun 2015.

Variabel kepemilikan manajerial yang diukur dengan proporsi kepemilikan saham oleh manajemen memperoleh nilai rata-rata 0,0402 dan standar deviasi 0,10194; dengan nilai minimum 0,00 yang ditemukan pada PT Citra Mineral Investindo Tbk (CITA) di tahun 2015-2017, PT Central Omega Resources Tbk (DKFT) di tahun 2015-2016, PT Elnusa Tbk (ELSA) di tahun 2015, PT Radiant Utama Interinsco Tbk (RUIS) d tahun 2015-2018, PT Golden Eagle Energy Tbk (SMMT), dan PT Timah Tbk (TINS) di tahun 2018; serta nilai maksimum 0,37 yang ditemukan pada PT Perdana Karya Perkasa Tbk (PKPK) di tahun 2015-2016. Variabel komisaris independen yang diukur dengan proporsi komisaris independen dalam dewan komisaris memperoleh nilai rata-rata 0,4056 dan standar deviasi 0,09518; dengan nilai minimum 0,25 yang terdapat pada PT Mitra Investindo Tbk (MITI) di tahun 2017; serta nilai maksimum 0,75 yang terdapat pada PT Golden Eagle Energy Tbk (SMMT) di tahun 2015. Variabel komite audit yang diukur dengan jumlah keseluruhan anggota komite audit memperoleh nilai rata-rata 3,1250 dan standar deviasi 0,67240; dengan nilai minimum 2,00 yang terdapat pada PT Ratu Prabu Energi Tbk (ARTI) di tahun 2015-2016, PT Golden Eagle Energy Tbk (SMMT) di tahun 2015, PT Citatah Mineral Investindo Tbk (CTTH) di tahun 2016-2018, dan PT Mitra Investindo Tbk (MITI) di tahun 2016; serta nilai maksimum 5,00 yang terdapat pada PT Aneka Tambang (ANTM) Tbk di tahun 2016. Variabel ukuran perusahaan memperoleh nilai ratarata 28,3715 dan standar deviasi 1,63821; dengan nilai minimum 25,57 yang dimiliki oleh PT Perdana Karya Perkasa Tbk di tahun 2018; serta nilai maksimum 31,14 yang dimiliki oleh PT Aneka Tambang Tbk (ANTM) di tahun 2018.

\subsection{Uji Asumsi Klasik}

Dalam penelitian ini terdapat empat uji asumsi klasik yang dilakukan yaitu:

\section{1) Uji Normalitas}

Menurut Ghozali (2018: 161) uji normalitas bertujuan untuk mengetahui apakah residual dalam model regresi berdistribusi secara normal atau tidak. Uji t dan uji F mengasumsikan bahwa residual berdistribusi secara normal, sehingga apabila terbukti residual tidak berdistribusi normal maka uji statistik menjadi tidak valid untuk jumlah sampel kecil. Penelitian ini menggunakan uji satistik nonparametik Kolmogorov-Smirnov.

\section{2) Uji Multikolinearitas}

Uji multikolinearitas bertujuan untuk mengetahui apakah terdapat korelasi antar variabel independen dalam model regresi (Ghozali, 2018: 107). Model regresi dapat dikatakan baik apabila tidak terjadi korelasi antar variabel independen di dalamnya atau variabel independen bersifat ortogonal. Multikolinearitas dapat dideteksi dengan melihat nilai tolerance dan nilai Variance Inflation Factor (VIF).

\section{3) Uji Autokorelasi}

Menurut Ghozali (2018: 111) uji autokorelasi bertujuan untuk menguji apakah terdapat korelasi antara residual pada periode tertentu dengan residual pada periode sebelumnya dalam model regresi 
linear. Model regresi yang baik adalah model regresi yang tidak terdapat autokorelasi di dalamnya. Dalam penelitian ini uji autokorelasi akan dilakukan dengan menggunakan uji Durbin Watson (DWtest).

\section{4) Uji Heteroskedastisitas}

Uji heteroskedastisitas bertujuan untuk menguji apakah terjadi ketidaksamaan variance dari residual suatu pengamatan ke pengamatan lainnya dalam model regresi (Ghozali, 2018: 137). Model regresi yang baik adalah model yang homoskedastisitas atau tidak terjadi heteroskedastisitas. Dalam penelitian ini, uji heteroskesdastisitas akan dilakukan melalui uji Glejser. Berikut ini adalah ringkasan hasil uji asumsi klasik:

\begin{tabular}{|c|c|c|c|c|c|}
\hline $\begin{array}{c}\text { Nama } \\
\text { Pengujian }\end{array}$ & Kriteria & \multicolumn{3}{|c|}{ Hasil } & Keputusan \\
\hline Normalitas & $\begin{array}{c}\text { Asymp.Sig > } \\
0,05\end{array}$ & \multicolumn{3}{|c|}{0,069} & Tidak tolak $\mathrm{H}_{0}$ \\
\hline \multirow{7}{*}{ Multikolinearitas } & \multirow{7}{*}{$\begin{array}{c}\text { Tolerance }>0,1 \\
\text { dan VIF }<10\end{array}$} & Variabel & Tolerance & VIF & \multirow{7}{*}{ Tidak tolak $\mathrm{H}_{0}$} \\
\hline & & PROF & 0,771 & 1,296 & \\
\hline & & LEV & 0,685 & 1,460 & \\
\hline & & KM & 0,644 & 1,552 & \\
\hline & & KI & 0,759 & 1,318 & \\
\hline & & KA & 0,503 & 1,989 & \\
\hline & & SIZE & 0,306 & 3,267 & \\
\hline Autokorelasi & $\begin{array}{c}\text { DU }<\text { DW }<4- \\
\text { DU, dengan nilai } \\
\text { DU }(K=6 ; n=48) \\
\text { adalah } 1,8265 \\
\end{array}$ & \multicolumn{3}{|c|}{1,831} & Tidak tolak $\mathrm{H}_{0}$ \\
\hline \multirow{7}{*}{ Heteroskedastisitas } & \multirow{7}{*}{$\mathrm{Sig}>0,05$} & $\mathrm{Val}$ & abel & Sig & \multirow{7}{*}{ Tidak tolak $\mathrm{H}_{0}$} \\
\hline & & & $\overline{\mathrm{OF}}$ & 0,860 & \\
\hline & & & $\mathrm{ZV}$ & 0,651 & \\
\hline & & & $\bar{M}$ & 0,552 & \\
\hline & & & $\mathrm{I}$ & 0,836 & \\
\hline & & \multicolumn{2}{|c|}{ KA } & 0,234 & \\
\hline & & \multicolumn{2}{|c|}{ SIZE } & 0,402 & \\
\hline
\end{tabular}

Berdasarkan tabel di atas dapat disimpulkan bahwa data yang digunakan dalam penelitian telah memenuhi seluruh uji asumsi klasik.

\subsection{Analisis Regresi Linear Berganda}

Analisis regresi linear berganda merupakan teknik analisis yang digunakan ketika terdapat lebih dari satu variabel independen yang dihipotesiskan berpengaruh terhadap satu variabel dependen (Sekaran \& Bougie, 2017: 138-139). Model regresi yang dibangun dalam penelitian ini adalah sebagai berikut:

$\operatorname{CSRD}=\beta_{0}+\beta_{1} P R O F+\beta_{2} L E V+\beta_{3} K M+\beta_{4} K I+\beta_{5} K A+\beta_{6} S I Z E+\varepsilon$

Keterangan:

CSRD : Pengungkapan Tanggung Jawab Sosial

$\beta_{0} \quad$ : Konstanta

$\beta_{1,2,3,4,5,6}$ : Koefisien regresi

PROF : Profitabilitas

KM : Kepemilikan Manajerial

LEV : Leverage

KI : Komisaris Independen

KA : Komite Audit

SIZE : Ukuran Perusahaan

$\varepsilon \quad:$ Error 
Berikut ini adalah hasil regresi linear berganda:

\begin{tabular}{|l|c|}
\hline Variabel & Unstandardized B \\
\hline Constant & $-3,255$ \\
\hline PROF & $-0,018$ \\
\hline LEV & 0,044 \\
\hline KM & 0,324 \\
\hline KI & 0,617 \\
\hline KA & 0,144 \\
\hline SIZE & 0,095 \\
\hline
\end{tabular}

Berdasarkan tabel di atas, diperoleh persamaan regresi linier sebagai berikut:

$$
\begin{aligned}
\mathrm{CSRD}= & -3,255-0,018 \mathrm{PROF}+0,044 \mathrm{LEV}+0,324 \mathrm{KM}+0,617 \mathrm{KI}+0,144 \mathrm{KA} \\
& +0,095 \mathrm{SIZE} \ldots \ldots \ldots \ldots \ldots \ldots \ldots \ldots \ldots \ldots . . . .(1)
\end{aligned}
$$

\section{1) Koefisien Determinasi}

Koefisien determinasi $\left(\mathrm{R}^{2}\right)$ mengukur kemampuan variabel-variabel independen dalam sebuah model dalam menjelaskan varians variabel dependennya (Ghozali, 2018: 97). Berikut adalah hasil koefisien determinasi:

\begin{tabular}{|c|c|c|}
\hline Model & Kriteria & $\mathbf{R}^{\mathbf{2}}$ \\
\hline 1 & Adjusted $\mathrm{R}^{2} 0-1$ & 0,663 \\
\hline
\end{tabular}

Berdasarkan tabel di atas dapat disimpulkan bahwa variabel independen mampu menjelaskan variabel dependen sebesar $66,3 \%$ sedangkan $33,7 \%$ sisanya dijelaskan variabel lain.

\section{2) Uji F}

Uji statistik F bertujuan untuk menguji apakah semua variabel independen dalam model regresi secara serentak atau bersama-sama mempengaruhi variabel dependen (Ghozali, 2018: 98).

\begin{tabular}{|c|c|c|c|}
\hline Model & Kriteria & Sig & Keputusan \\
\hline 1 & Sig $<0.05$ & 0.000 & Tolak $\mathrm{H}_{0}$ \\
\hline
\end{tabular}

Berdasarkan tabel di atas diperoleh nilai signifikansi di bawah 0,05, sehingga dapat dikatakan bahwa model signifikan atau semua variabel independen secara bersama-sama memiliki pengaruh terhadap variabel dependen.

\section{3) Uji t}

Uji t digunakan untuk mengetahui seberapa signifikan pengaruh masing-masing variabel independen (secara parsial) dalam menjelaskan varians variabel dependen (Ghozali, 2018: 98-99). Pengujian menggunakan nilai signifikansi $\alpha=0,05$ atau $5 \%$.

\begin{tabular}{|c|c|c|c|c|}
\hline Variabel & Kriteria & Sig. & Sig. (1-tailed) & Keputusan \\
\hline PROF & & 0.916 & 0.4580 & Tidak Tolak $\mathrm{H}_{0}$ \\
\hline
\end{tabular}




\begin{tabular}{|c|c|c|c|c|}
\hline LEV & \multirow{4}{*}{$\begin{array}{c}\text { Sig. (1-tailed) } \\
0,05\end{array}$} & 0.423 & 0.2115 & Tidak Tolak $\mathrm{H}_{0}$ \\
\hline KM & & 0.211 & 0.1055 & Tidak Tolak $\mathrm{H}_{0}$ \\
\hline $\mathrm{KI}$ & & 0.019 & 0.0095 & Tolak $\mathrm{H}_{0}$ \\
\hline KA & & 0.002 & 0.0010 & Tolak $\mathrm{H}_{0}$ \\
\hline
\end{tabular}

Berdasarkan tabel di atas variabel profitabilitas memiliki nilai sig. (1-tailed) sebesar 0,4580. Nilai signifikansi tersebut lebih besar dari tingkat signifikansi $0,05(\alpha=5 \%)$, maka tidak tolak $\mathrm{H}_{0}$ atau dapat dikatakan bahwa profitabilitas tidak berpengaruh signifikan terhadap pengungkapan tanggung jawab sosial.

Variabel leverage memiliki nilai sig. (1-tailed) sebesar 0,2115. Nilai signifikansi tersebut lebih besar dari tingkat signifikansi $0,05(\alpha=5 \%)$, maka tidak tolak $\mathrm{H}_{0}$ atau dapat dikatakan bahwa leverage tidak berpengaruh signifikan terhadap pengungkapan tanggung jawab sosial.

Variabel kepemilikan manajerial memiliki nilai sig. (1-tailed) sebesar 0,1055. Nilai signifikansi tersebut lebih besar dari tingkat signifikansi $0,05(\alpha=5 \%)$, maka tidak tolak $\mathrm{H}_{0}$ atau dapat dikatakan bahwa kepemilikan manajerial tidak berpengaruh signifikan terhadap pengungkapan tanggung jawab sosial.

Variabel komisaris independen memiliki nilai sig. (1-tailed) sebesar 0,0095. Nilai signifikansi tersebut lebih kecil dari tingkat signifikansi $0,05(\alpha=5 \%)$, maka tolak $\mathrm{H}_{0}$ atau dapat dikatakan bahwa komisaris independen berpengaruh signifikan terhadap pengungkapan tanggung jawab sosial, dengan arah positif yang diperlihatkan nilai koefisien regresinya sebesar 0,617.

Variabel komite audit memiliki nilai sig. (1-tailed) sebesar 0,0010. Nilai signifikansi tersebut lebih kecil dari tingkat signifikansi $0,05(\alpha=5 \%)$, maka tolak $\mathrm{H}_{0}$ atau dapat dikatakan bahwa komite audit berpengaruh signifikan terhadap pengungkapan tanggung jawab sosial, dengan arah positif yang diperlihatkan nilai koefisien regresinya sebesar 0,144 .

\subsection{Pembahasan}

\section{1) Pengaruh Profitabilitas terhadap Pengungkapan Tanggung Jawab Sosial Perusahaan}

Berdasarkan hasil pengujian, terlihat bahwa profitabilitas tidak berpengaruh secara signifikan terhadap pengungkapan tanggung jawab sosial perusahaan, dengan demikian hipotesis ditolak. Hasil penelitian ini sejalan dengan penelitian Dewi \& Sedana (2019) yang menemukan bahwa profitabilitas tidak mempengaruhi pengungkapan tanggung jawab sosial perusahaan secara signifikan. Namun hasil penelitian ini bertolak belakang dengan penelitian Handoyo \& Jakasurya (2017) yang menunjukkan adanya pengaruh positif profitabilitas terhadap pengungkapan tanggung jawab sosial.

Menurut Indraswari (2017) perusahaan dengan profitabilitas tinggi tidak selalu mengungkapkan tanggung jawab sosialnya secara lebih luas karena perusahaan lebih berorientasi pada laba. Ketika kinerja keuangan sudah baik manajemen akan cenderung tidak memperhatikan pengungkapan tanggung jawab sosialnya guna menonjolkan informasi terkait kinerja perusahaan. Hal ini tentu saja bertentangan dengan teori keagenan di mana situasi seperti ini justru dapat memperbesar asimetri informasi antara agen dan prinsipal. Selain itu perusahaan dengan profitabilitas rendah juga tidak selalu mengurangi pengungkapan informasinya. Fenomena ini dapat terjadi karena adanya keinginan manajemen untuk menunjukkan good news berupa pelaksanaan tanggung jawab sosial.

\section{2) Pengaruh Leverage terhadap Pengungkapan Tanggung Jawab Sosial Perusahaan}

Berdasarkan hasil pengujian, terlihat bahwa leverage tidak berpengaruh secara signifikan terhadap pengungkapan tanggung jawab sosial perusahaan, dengan demikian hipotesis ditolak. Hasil penelitian ini sejalan dengan penelitian Indrayenti \& Jenny (2018) yang menunjukkan tidak terdapat cukup bukti bahwa leverage berpengaruh terhadap pengungkapan tanggung jawab sosial perusahaan. Akan tetapi hasil yang berbeda diperlihatkan dalam penelitian Kastamutuwardhani \& Khairunnisa (2019) yang menyimpulkan adanya pengaruh negatif leverage terhadap pengungkapan tanggung jawab sosial. 
Tingginya tingkat leverage perusahaan mengindikasikan kurang baiknya kinerja keuangan perusahaan. Perusahaan akan berupaya untuk menunjukkan performa baik perusahaan dalam aktivitas lain seperti halnya tanggung jawab sosial guna mengalihkan isu buruknya kinerja keuangan. Hal ini dilakukan untuk mempertahankan citra perusahaan di mata para pemangku kepentingan. Kemudian kecenderungan perusahaan untuk melakukan pengungkapan tanggung jawab sosial yang bergantung pada kepekaannya terhadap masyarakat menjadi faktor lain tidak signifikannya pengaruh leverage terhadap CSRD karena perusahaan tidak terlalu memperhatikan leverage dalam melakukan pengungkapan.

\section{3) Pengaruh Kepemilikan Manajerial terhadap Pengungkapan Tanggung Jawab Sosial Perusahaan}

Berdasarkan hasil pengujian, terlihat bahwa kepemilikan manajerial tidak berpengaruh secara signifikan terhadap pengungkapan tanggung jawab sosial perusahaan, dengan demikian hipotesis ditolak. Hasil penelitian ini sejalan dengan penelitian Permadiswara \& Sujana (2018) yang menunjukkan bahwa kepemilikan manajerial tidak berpengaruh signifikan terhadap pengungkapan tanggung jawab sosial perusahaan. Di lain sisi hasil penelitian ini berlawanan dengan penelitian Ariswari \& Damayanthi (2019) yang menemukan pengaruh positif signifikan kepemilikan manajerial terhadap pengungkapan tanggung jawab sosial perusahaan.

Kurang signifikannya pengaruh kepemilikan manajerial terhadap pengungkapan tanggung jawab sosial dapat disebabkan oleh kecenderungan manajemen untuk berorientasi pada peningkatan nilai perusahaan yang memberikan keuntungan bagi dirinya sebagai agen dan prinsipal. Rendahnya persentase kepemilikan manajerial juga dapat menjadi pemicu tidak adanya pengaruh kepemilikan manajerial terhadap CSRD. Rata-rata kepemilikan manajerial pada perusahaan sampel hanya sebesar 4,02\% atau di bawah 5\%, di mana kepemilikan manajerial di bawah 5\% termasuk dalam kategori rendah menurut Husnan (2000) dalam Nuringsih (2005). Sehingga pada akhirnya kepemilikan manajerial tidak mempengaruhi CSRD secara signifikan.

\section{4) Pengaruh Komisaris Independen terhadap Pengungkapan Tanggung Jawab Sosial Perusahaan}

Berdasarkan hasil pengujian, terlihat bahwa komisaris independen berpengaruh secara signifikan dengan arah positif terhadap pengungkapan tanggung jawab sosial perusahaan, dengan demikian hipotesis diterima. Hasil penelitian ini sejalan dengan penelitian Juniartha \& Dewi (2017); Yuliani (2019) di mana terdapat cukup bukti bahwa komisaris independen berpengaruh positif terhadap pengungkapan tanggung jawab sosial. Bertolak belakang dengan hasil penelitian ini, Solikhah \& Winarsih (2016) dalam penelitiannya menyatakan komisaris independen memiliki pengaruh negatif terhadap pengungkapan CSR, sementara penelitian Jayanti \& Husaini (2017) memperlihatkan tidak adanya pengaruh komisaris independen terhadap pengungkapan CSR.

Komisaris independen merupakan pihak yang netral dalam melaksanakan fungsi pengawasannya, sehingga keberadaannya akan membuat kebijakan perusahaan dilakukan secara objektif tanpa memberatkan kepentingan pribadi manajemen. Juniartha \& Dewi (2017) mengatakan sejalan dengan netralitas yang dimiliki oleh komisaris independen, maka semakin besar proporsi komisaris independen akan semakin luas pengungkapan tanggung jawab sosialnya. Hal ini disebabkan oleh sikap komisaris independen yang senantiasa berupaya mewujudkan kepentingan umum termasuk kepentingan pemilik dan stakeholder dengan tidak memihak pada manajemen perusahaan.

\section{5) Pengaruh Komite Audit terhadap Pengungkapan Tanggung Jawab Sosial Perusahaan}

Berdasarkan hasil pengujian, terlihat bahwa komite audit berpengaruh secara signifikan dengan arah positif terhadap pengungkapan tanggung jawab sosial perusahaan, dengan demikian hipotesis diterima. Hasil penelitian ini sejalan dengan penelitian Laksmi \& Kamila (2018) yang memperoleh hasil bahwa komite audit berpengaruh positif terhadap pengungkapan CSR. Bertolak belakang 
dengan hasil penelitian ini, Sholihin \& Aulia (2018) menyatakan bahwa pengaruh komite audit terhadap pengungkapan tanggung jawab sosial perusahaan adalah tidak signifikan.

Aniktia \& Khafid (2015) menjelaskan bahwa keberadaan komite audit mendorong manajemen untuk mengungkapkan tanggung jawab sosialnya melalui sustainability report guna mengomunikasikan informasi tersebut kepada stakeholder sehingga perusahaan memperoleh kepercayaan dari para pemangku kepentingan. Hal ini terkait dengan fungsi pengawasan yang dimiliki oleh komite audit, sehingga keberadaannya akan memaksimalkan pengungkapan dan pengendalian internal perusahaan (Collier, 1993). Maka semakin banyak jumlah komite audit akan semakin kuat fungsi pengawasannya, sehingga menekan manajemen untuk semakin luas melakukan pengungkapan tanggung jawab sosialnya.

\section{SIMPULAN DAN SARAN}

Berdasarkan hasil pengujian dan pembahasan yang telah dilakukan maka dapat disimpulkan bahwa tidak terdapat cukup bukti bahwa profitabilitas, leverage, dan kepemilikan manajerial berpengaruh terhadap pengungkapan tanggung jawab sosial perusahaan. Akan tetapi ditemukan cukup bukti bahwa komisaris independen dan komite audit berpengaruh terhadap pengungkapan tanggung jawab sosial perusahaan.

Saran yang dapat diberikan bagi perusahaan adalah untuk memperhatikan peningkatan pengungkapan tanggung jawab sosialnya sesuai dengan prioritas tema atas aspek kontekstual yang mendasarinya. Bagi pengguna laporan diharapkan untuk mempertimbangkan aspek pengungkapan tanggung jawab sosial dalam pengambilan keputusannya. Sementara bagi peneliti selanjutnya disarankan untuk meneliti sektor yang sebagian besar perusahaannya telah mempublikasikan laporan keberlanjutan dan dapat menggunakan proksi lain untuk variabel yang belum berpengaruh signifikan.

\section{DAFTAR PUSTAKA}

Akanfe, S. K., Michael, S. O., \& Bose, A. D. (2017). Determinant of Corporate Social Responsibility Disclosure in Nigeria. International Journal of Academic Research in Business and Social Sciences, 7(7), 565-580.

Aniktia, R., \& Khafid, M. (2015). Pengaruh Mekaniseme Good Corporate Governance dan Kinerja Keuangan Terhadap Pengungkapan Sustainability Report. Accounting Analysis Journal.

Ariswari, P. M. A., \& Damayanthi, I. G. A. E. (2019). Pengaruh Profitabilitas, Leverage, dan Kepemilikan Manajemen pada Pengungkapan CSR dengan Ukuran Perusahaan sebagai Variabel Kontrol, 1920-1933.

Asmeri, R., Alvionita, T., \& Gunardi, A. (2017). CSR Disclosures in the Mining Industry: Empirical Evidence from Listed Mining Firms in Indonesia. Indonesian Journal of Sustainability Accounting and Management, 1(1), 16.

Bansal, S., Perez, M. V. L., \& Ariza, L. R. (2018). Board Independence and Corporate Social Responsibility Disclosure: The Mediating Role of the Presence of Family Ownership. Administrative Sciences, 8(3), 33.

Bempah, R. P. (2017). Tak Dapat Dana CSR PT Antam, Eks Gurandil di Bogor mengadu ke Istana.

Buallay, A., \& Al-Ajmi, J. (2019). The Role of Audit Committee Attributes in Corporate Sustainability Reporting: Evidence from Banks in the Gulf Cooperation Council. Journal of Applied Accounting Research.

Cahyadi, R. T., Purwanti, L., \& Mardiati, E. (2018). Pengaruh Profitabilitas, Dewan Komisaris, Komisaris Independen dan Risiko Idiosinkratis Terhadap Dividend Payout Ratio. Jurnal Economia, 14(1), 99.

Cahyono, D. D., Andini, R., \& Raharjo, K. (2016). Pengaruh Komite Audit, Kepemilikan 
Institusional, Dewan Komisaris, Ukuran Perusahaan, Leverage, dan Profitabilitas terhadap Tindakan Penghindaran Pajak pada Perusahaan Perbankan yang Listing BEI Periode tahun 2011-2013. Journal of Accounting, 2, 5-24.

Collier, P. (1993). Factors Affecting Formation of Audit Committees in Major UK Listed Companies.

Dewi, P. A. C., \& Sedana, I. B. P. (2019). Pengaruh Profitabilitas , Ukuran Perusahaan, dan Leverage terhadap Pengungkapan Corporate Social Responsibility. Jurnal Manajemen, 8(11), 242262.

Dewinta, I. A. R., \& Setiawan, P. E. (2016). Pengaruh Ukuran Perusahaan, Umur Perusahaan, Profitabilitas, Leverage, dan Pertumbuhan Penjualan Terhadap Tax Avoidance. E-Jurnal Akuntansi, 14(3), 1584-1615.

Dyduch, J., \& Krasodomska, J. (2017). Determinants of Corporate Social Responsibility Disclosure: an Empirical Study of Polish listed companies. Sustainability (Switzerland), 9(11).

Edison, A. (2017). Struktur Kepemilikan Asing, Kepemilikan Institusional dan Kepemilikan Manajerial Pengaruhnya Terhadap Luas Pengungkapan Corporate Social Responsibility (CSR). Jurnal Bisnis Dan Manajemen, 11(2), 164.

Elkington, J. (1997). Cannibal with Forks: The Triple Bottom Line oF 21st Century Business. Capstone Pubishing Limited.

Fajaryani, A. (2015). Analisis Faktor-Faktor yang Mempengaruhi Integritas Laporan Keuangan.

Ghozali, I. (2018). Aplikasi Analisis Multivariate Dengan Program IBM SPSS 25 (9 th $^{\text {th }}$ Edition). Semarang: Badan Penerbit Universitas Diponegoro.

Habbash, M. (2015). Corporate Governance and Corporate Social Responsibility Disclosure: Evidence from Saudi Arabia. International Scientific Conference on Economic and Social Development.

Handoyo, S., \& Jakasurya, T. (2017). Analisa Variabel yang Mempengaruhi Pengungkapan Informasi Tanggung Jawab Sosial Perusahaan. Matrik: Jurnal Manajemen, Strategi Bisnis Dan Kewirausahaan.

Hasnia, \& Rofingatun, S. (2017). Pengaruh Profitabilitas, Likuiditas, Growth dan Media Exposure terhadap Pengungkapan Tanggung Jawab Sosial Perusahaan. Jurnal Akuntansi \& Keuangan Daerah, 12(2014), 56-71.

Indraswari, I. G. A. L. (2017). Pengaruh Profitabilitas, Pertumbuhan Perusahaan, Kapitalisasi Pasar dan Kepemilikan Publik pada Tingkat Pengungkapan CSR. E-Jurnal Akuntansi Universitas Udayana, 20(2), 1219-1248.

Indrayenti, \& Jenny. (2018). Analisis Pengaruh Ukuran Perusahaan, Ukuran Dewan Komisaris, Profitabilitas, dan Leverage terhadap Pengungkapan Tanggung Jawab Sosial pada Sektor Industri Barang Konsumsi yang Terdaftar di Bursa Efek Indonesia Periode 2014-2016. Jurnal Akuntansi dan Keuangan, 9(2).

Issa, A. I. F. (2017). The Factors Influencing Corporate Social Responsibility Disclosure in the Kingdom of Saudi Arabia. Australian Journal of Basic and Applied Sciences, 11(July), 119.

Jayanti, K. R., \& Husaini, A. (2017). Pengaruh Good Corporate Governance dan Profitabilitas terhadap Pengungkapan CSRP. Jurnal Administrasi Bisnis (JAB), 59(1), 16-22.

Julianto, M., \& Sjarief, J. (2016). Analisis Pengaruh Kinerja Lingkungan, Manajemen Laba, Ukuran Perusahaan, dan Profitabilitas Terhadap Pengungkapan Lingkungan Pada Perusahaan Manufaktur yang Terdaftar Di Bursa Efek Indonesia. Jurnal Akuntansi, 9(2), 147-171. 
Juniartha, I. M., \& Dewi, R. R. (2017). Pengaruh Proporsi Komisaris Independen, Kinerja Lingkungan, dan Pertumbuhan Perusahaan Terhadap Pengungkapan Lingkungan. Jurnal Akuntansi Trisakti, 4(2), 117.

Kastamutuwardhani, D., \& Khairunnisa. (2019). Pengaruh Profitabilitas, Leverage, dan Ukuran Perusahaan Terhadap Pengungkapan CSR (Studi Kasus pada Perusahaan yang Terdaftar pada Indeks SRI-Kehati tahun 2013-2017). Jurnal Akuntansi, Audit, Dan SIA, 3, 1689-1699.

Krisna, A. D., \& Suhardianto, N. (2016). Faktor-Faktor yang Mempengaruhi Pengungkapan Tanggung Jawab Sosial. Jurnal Akuntansi Dan Keuangan, 18(2), 119-127.

Laksmi, A. C., \& Kamila, Z. (2018). The Effect of GCG and Earnings Management to Corporate Social Responsibility Disclosure. Academy of Accounting and Financial Studies Journal, 22(1).

Lessambo, F. I. (2018). Financial Statements Analysis and Reporting.

Masriadi. (2019). Cium Bau Busuk, Warga Aceh Timur Demo Perusahaan Tambang.

Mousa, G. A., Desoky, A. M., \& Khan, G. U. (2018). The Association between Corporate Governance and Corporate Social Responsibility Disclosure-Evidence From Gulf Cooperation Council Countries. Academy of Accounting and Financial Studies Journal, 22(4).

Naseem, M. A., Riaz, S., Rehman, Ikram, A., \& Malik, F. (2017). Impact of board Characteristics on Corporate Social Responsibility Disclosure. Journal of Applied Business Research.

Nuringsih, K. (2005). Analisis Pengaruh Kepemilikan Manajerial, Kebijakan Utang, ROA, dan Ukuran Perusahaan Terhadap Kebijakan Dividen: Studi 1995-1996, 2(2), 103-123.

Nurziah, F., \& Darmawati, D. (2014). Analisis Pengaruh Corporate Governance, Kepemilikan Manajerial dan Kepemilikan Institusional Terhadap Intellectual Capital Disclosure. Finance and Banking Journal, 16(2), 172-192.

Octaviani, S., \& Yap, S. (2016). Pengaruh Corporate Governance , Profitabilitas , Likuiditas Dan Solvabilitas Terhadap Corporate Social Responsibility Disclosure. Jurnal Bisnis Dan Akuntansi.

Otoritas Jasa Keuangan. (2017). Peraturan Otoritas Jasa Keuangan Nomor 13/POJK.03/2017 tentang Penggunaan Jasa Akuntan Publik dan Kantor Akuntan Publik Dalam Kegiatan Jasa Keuangan.

Pemerintah. (2007). Undang-Undang No 40 tahun 2007.

Pemerintah. (2009). Undang-Undang No 32 tahun 2009.

Permadiswara, K. Y., \& Sujana, I. K. (2018). Pengaruh Profitabilitas, Ukuran Perusahaan, Kepemilikan Manajemen dan Media Exposure Pada Pengungkapan Corporate Social Responsibility. E-Jurnal Akuntansi, 25, 690.

Purwanti, T., \& Kalbuana, N. (2016). Financial Statement Disclosure Bank Pembangunan. Magistra.

Putri, I., \& Suprasto H, B. (2016). Pengaruh Tanggung Jawab Sosial Perusahaan dan Mekanisme Tata Kelola Perusahaan Terhadap Nilai Perusahaan. E-Jurnal Akuntansi, 15(1), 667-694.

Putri, R. K. (2017). Pengaruh Ukuran Perusahaan, Profitabilitas, Leverage, Likuiditas, dan Basis Kepemilikan terhadap Corporate Social Responsibility pada Perusahaan Pertambangan yang Tedaftar di Bursa Efek Indonesia periode 2012-2014. Journal of Management, 4.

Rifqiyah, R. F. (2016). Pengaruh Profitabilitas, Ukuran Perusahaan, Kepemilikan Saham Publik Terhadap Pengungkapan CSR. Sekolah Tinggi Ilmu Ekonomi Perbanas.

Rivandi, M., Saleh, S. M., \& Septiano, R. (2017). Leverage, Profitabilitas, Ukuran Perusahaan, 
Pengungkapan Corporate Social Responsibility Dengan Pendekatan Kausalitas. Jurnal Pundi.

Robiah, A. M., \& Erawati, T. (2017). Pengaruh Leverage , Size , dan Kepemilikan Manajemen Terhadap Corporate Social Responsibility Disclosure. Jurnal Akuntansi Dewantara.

Robinson, T. R., Henry, E., Pirie, W. L., \& Broihahn, M. A. (2015). International Financial Statement Analysis (Third Edit).

Rokhlinasari, S. (2016). Teori-Teori dalam Pengungkapan Informasi Corporate Social Responsibility Perbankan. Jurnal Ekonomi Dan Perbankan, 1-11.

Rokhman, M. T. N. (2015). Pengaruh Size, Profitabilitas, dan Likuiditas Terhadap (CSR) (Studi Empiris pada Perusahaan LQ-45 yang Terdaftar di BEI). Jurnal Ilmiah - Vidya, 25(2), 195203.

Sari, R. Y. R., \& Asiah, A. N. (2016). Pengaruh Leverage Terhadap Profitabilitas Pada Perusahaan Manufaktur yang Terdaftar Di BEIPeriode 2010-2013. Manajemen dan Akuntansi.

Sekaran, U., \& Bougie, R. (2017). Metode Penelitian untuk Bisnis. Salemba.

Sholihin, M. R., \& Aulia, Y. (2018). Analisis Faktor-Faktor yang Mempengaruhi Pengungkapan Corporate Social Responsibility (Studi Empiris Perusahaan Manufaktur yang Terdaftar Di Bursa Efek Indonesia). Jurnal Analisa Akuntansi Dan Perpajakan, 2(2), 110-130.

Simamora, E., Nasir, A., \& Safitri, D. (2017). Faktor-faktor yang Mempengaruhi Pengungkapan Tanggung Jawab Sosial Perusahaan Pada Perusahaan Manufaktur Yang Terdaftar Di BEI Tahun 2014. Jurnal Online Mahasiswa Fakultas Ekonomi Universitas Riau, 4(1), 841-855.

Singgih, M., Farida, L., \& Iwanda, R. A. (2017). Determinan Tingkat Pengungkapan Tanggung Jawab Sosial Perusahaan Manufaktur Sub Sektor Makanan dan Minuman di BEI, 11(3), 259-270.

Solikhah, B., \& Winarsih, A. M. (2016). Pengaruh Liputan Media, Kepekaan Industri, Dan Struktur Tata Kelola Perusahaan Terhadap Kualitas Pengungkapan Lingkungan. Jurnal Akuntansi Dan Keuangan Indonesia, 13(1), 1-22.

Suastini, N. M., Purbawangsa, I. B. A., \& Rahyuda, H. (2016). Pertumbuhan Perusahaan Terhadap Nilai Perusahaan Pada Perusahaan Manufaktur Di Bursa Eefek Indonesia (Struktur Modal sebagai Variabel Moderasi ) Jurnal Ekonomi dan Bisnis Universitas Udayana, 5(1), 143172.

Sukasih, A., \& Sugiyanto, E. (2017). Pengaruh Struktur Good Corporate Governance dan Kinerja Lingkungan terhadap Pengungkapan Corporate Social Responsibility. Riset Akuntansi Dan Keuangan Indonesia, 2(2), 121-131.

Sumilat, H., \& Destriana, N. (2017). Faktor-Faktor yang Mempengaruhi Pengungkapan Corporate Social Responsibility ( CSR) dalam Laporan. Jurnal Bisnis Dan Akuntansi, 19(2), 129-140.

Susanto, Y. K., \& Joshua, D. (2018). Pengaruh tata kelola perusahaan dan Karakteristik Perusahaan Terhadap Pengungkapan Tanggung Jawab Sosial Perusahaan, 2, 572-590.

Trinanda, S. M., Yahdi, M., \& Rizal, N. (2018). Analisis Pengaruh Size, Profitabilitas, dan Leverage Terhadap Corporate Social Responsibility Disclosure. Progress Conference, 1(1), 305-308.

Villiers, C. de, \& Marques, A. (2016). Corporate Social Responsibility, Country-Level, Predispositions and The Consequences of Chosing a Level of Disclosure.

Wahyuningsih, A., \& Mahdar, N. M. (2018). Pengaruh Size , Leverage dan Profitabilitas Terhadap Pengungkapan Csr Pada Perusahaan Manufaktur yang Terdaftar di Bursa Efek Indonesia. Jurnal Bisnis Dan Komunikasi, 5(1), 27-36. 
Wiyuda, A., \& Pramono, H. (2017). Pengaruh Good Corporate Governance, Karakteristik Perusahaan terhadap Luas Pengungkapan CSR pada Perusahaan terdaftar di BEI. Kompartemen, XV(1).

Wulandari, A. A. A. I., \& Sudana, I. P. (2018). Pengaruh Profitabilitas, Kepemilikan Asing, Kepemilikan Manajemen, dan Leverage Pada Intensitas Pengungkapan Corporate Social Responsibility. E-Jurnal Akuntansi, 22, 1445.

Yuliani. (2019). Pengaruh Mekanisme Good Corporate Governance Pada Pengungkapan Tanggung Jawab Sosial Perusahaan yang Tergabung dalam Indeks Kompas 100. JWM (Jurnal Wawasan Manajemen), 6(3), 209.

Zhou, C. (2019). Effects of Corporate Governance on The Decision to Voluntarily Disclose Corporate Social Responsibility Reports: Evidence from China. Applied Economics, 51(55), 5900 5910 . 